\title{
Possibilities of Heat Pump Integration for the Renovation of Dwelling Houses
}

\author{
Vytautas Martinaitis ${ }^{1}$, Giedrius Siupsinskas ${ }^{2}{ }^{1-2}$ Department of Buildings Energetics, \\ Vilnius Gediminas Technical University
}

\begin{abstract}
The technical solutions for the installation of heat pumps in individual houses are well known, but its integration in the existing systems in dwelling houses is not common. Heat pump technology is referred to as renewable but would have technical, economic and environmental impact on the whole existing heat supply system in a dwelling house. The aim of this article is to investigate the possibility of using heat pumps for supplying heat to the existing residential buildings.

This article examines the possibilities to supplement the engineering systems with additional heat pumps. The smallest heat pump end-user group is the dwelling stairwell. The possibility to use heat pumps in a separate apartment has not been analysed.

This article analyses the integration of heat pumps for residential heat supply in the building. The primary heat source is the exhaust air or wastewater. All calculations have been made for several real existing dwelling houses in Birštonas town (Lithuania) within the framework of the CONCERTO Eco-Life project. The analysis also provides economic and environmental assessment of the alternatives.

This research was supported by EC FP7 CONCERTO program ("Sustainable Zero Carbon ECO-Town Developments Improving Quality of Life across EU - ECO-Life" (ECO-Life Project) Contract No. TREN/FP7EN/239497/"ECOLIFE").
\end{abstract}

Keywords - Heat pump, dwelling house renovation, technical, economic and environmental assessment

\section{INTRODUCTION}

Energy efficiency of buildings is one of the leading topics of the European Union policy. Two different aspects are defined: renovation of the existing buildings and construction of new buildings. In both aspects the greatest attention is paid to the renewable energy resources and efficient transformers of fossil fuel energy. Both these aspects are unified by heat pumps (HP), though they are not apparently a widely used technology for heat supply to residential buildings. This article analyses the possibility of HP integration for heat supply in renovated dwelling houses in Lithuania. The specific feature of heat supply of these houses - the main part of heat is supplied from the district heating system (DHS). The possible alternatives of building service systems (heating, ventilation, domestic hot and cold water) are analysed in their energy audits and feasibility studies. This article examines the possibilities of HP integration in the renovated building services systems. The smallest group of HP end-users is a stairwell of a four-storey residential building. The possibilities to integrate HP in a separate apartment or buildings' disconnection from DHS is not the topic of this article.
HP systems offer economic alternatives for recovering heat from different sources for use in various industrial, commercial and residential applications. A review of the major hybrid HP systems suitable for application with various heat sources is presented [1]. The evolution of new hybrid systems has also enabled HP to perform efficiently with wider applications and markedly reducing carbon emission. The ventilation, heating and cooling of a building can be provided by advanced mechanical ventilation heat recovery systems which incorporate HP [2, 3]. Different systems with combinations of solar collectors and ground-source HP are simulated and optimized $[4,5]$. A novel heating and cooling concept is developed to make use of rainwater for HP of HVAC systems. [6, 7]

In FW6 and FW7 Concerto projects or countries with cooler climate, solutions with HP are also applied.

One of the objectives of the project Concerto Class1 is "to optimize the integration of low-energy building technologies with supply and distribution technologies". HP is planned to cover about 26\% of the required 2.7 MWh of heat in Stenløse community. Energy demand for heating in one group of buildings reaches $30-34 \mathrm{kWh} / \mathrm{m}^{2}$ and in the other one - about $16 \mathrm{kWh} / \mathrm{m}^{2}$ [8].

One of the scientific research and innovation activities of the project Concerto Green Solar Cities is "combination of large-scale solar heat device with low temperature micro network, integrating HP into network and increasing the general effectiveness of solar device". In Salzburg (Austria), the project of $2000 \mathrm{~m}^{2}$ of solar collectors is planned with 200 $\mathrm{m}^{3}$ accumulation tank and integrated HP [9].

HP integration possibilities are widely discussed in the Intelligent Energy Europe project Promotion of Efficient Heat Pumps for Heating (ProHeatPump) [10]. While performing this work, the information of the Intelligent Energy Europe Sentro project was methodically useful [11]. In the context of the analysed problem, the research results for the Nordic countries are noteworthy [12]. In these researches, the life cycle analysis is used. It is confirmed that the Ecodesign concept for energy consuming and related products [13] is widely used in many spheres voluntarily, and it is likely to become obligatory for buildings.

Solar thermal energy and HP combination in one system seems to serve the purpose. The results of the solar heat system's combination with other generators in nine buildings [14] are presented, in four of which HPs are integrated. Thorough research shows that exhaust air HP needs less additional investments than air-water HP or ground (vertical 
bore) HP [15]. In Germany, 40-50 \% of all passive houses use the integrated HP system for heating and domestic hot water [16]. Usually, heat source is exhaust ventilation air, often combined with preheating of the supplied air or cooling in a ground heat exchanger [17]. Nowadays in market very high efficiencies of heat recovery from the exhaust air are expected. Such efficiencies are reached in standard conditions and are far from the seasonal efficiency which the end-user is concerned about. It should be noted that in the mentioned estimations the seasonal efficiency is defined in three values (30, 55 and $70 \%)$ and thus, it poses high confidence [15].

Besides air, another warm flow outgoing from a building is waste water (WW). A very well structured information on the possibilities of waste water heat usage is found in [18]. For example, in Switzerland, about 2 TWh of heating of premises could be covered by WW [19], and it makes $7 \%$ of the country's heat demand for heating. It should be noted that, in the future, after the thermal characteristics of building will be gradually improved, the flow of air and warm water from the building shall change very slightly, and thus should receive more attention.

\section{ESTIMATED SELECTION OF HP ALTERNATIVES}

In this article, a slightly modified and amended SENTRO renewable energy evaluation tool [11] was used for the selection of HP alternatives. The tool provides the possibility of selection which is assessed according to technical, financial, organizational and environmental parameters. The weight coefficients given for these parameters help to compare the probability of the solution with the effort required to implement it. When the indicator is less than $33 \%$, the solution is evidently unacceptable, and, when it reaches $75 \%$, the solution is worth paying attention to. Mediate values might have various descriptions, but the selection of such alternatives is more or less arguable and needs a more thorough argumentation.

Two separate HP groups are estimated - ground source HP (G) and waste heat HP (R). In the first case, HP needs a heat collector in the ground. In the second case, HP uses waste heat of the maintained building, which normally is exhaust air (ExAir) or WW. The aggregated indicators of these two groups ( $\mathrm{G}$ and $\mathrm{R}$ ) according to SENTRO are presented in Table I.

TABLE I

AGGREGATED INDICATORS OF HEAT PUMP TECHNOLOGY ASSESSMENT

\begin{tabular}{|c|c|c|c|c|c|}
\hline Group & \multicolumn{1}{|c|}{ HP technology } & $\begin{array}{c}\text { Technical } \\
\text { parameters }\end{array}$ & $\begin{array}{c}\text { Financial } \\
\text { parameters }\end{array}$ & $\begin{array}{c}\text { Organisational } \\
\text { parameters }\end{array}$ & $\begin{array}{c}\text { Environmental } \\
\text { parameters } \\
\text { probability }\end{array}$ \\
\hline HP_G & Ground HP for heating & $61 \%$ & $75 \%$ & $58 \%$ & $53 \%$ \\
\hline HP_R & Other (not ground) HP & $89 \%$ & $75 \%$ & $75 \%$ & $33 \%$ \\
\hline
\end{tabular}

The technical parameters cover the assessment of ground surface suitability, exhaust ventilation, demand of heat and domestic hot water, type of heating system and HP area.

The financial parameters cover the assessment of investment and operational maintenance costs, the system's life cycle costs and an appropriate subsidy scheme.

The organizational parameters include the assessment of the drilling and/or construction permit, quality of the system, sufficient system supply and qualified staff.

The environmental parameters cover the assessment of impact to global warming. According to the size of buildings, for a successful HP, installation HP_R alternatives are further analysed.

\section{POSSIBLE TECHNICAL ALTERNATIVES}

The article examines the possible technical alternatives of HP installation in the services systems of renovated fourstorey dwelling houses with 40 apartments built in 1970 . They have a water to water plate heat exchanger, natural ventilation system, direct/instantaneous domestic hot water system (DHW) with recirculation. So, the reference alternative is when HPs are not installed. The technically possible alternatives, when the building's main heat demand is supplied by DHS, are presented below.

HP_R1. Usage of heat recovered from mechanical exhaust air for HP, when there is no mechanical air supply system and HP is installed in a stairwell's bivalent (together with DHS) semi-accumulation domestic hot water preparation system.

HP_R2. Usage of heat recovered from mechanical exhaust air for HP, when there is a mechanical air supply system and HP is installed in a stairwell's air handling unit instead of air preheating section after or instead of plate recuperator.

HP_R3. Usage of heat from the building's waste water for HP which heats up the building's recirculation pipes network of domestic hot water.

The main technical indicators of a heat user are used in these calculations:

There are ten apartments in a stairwell (total area $\sim 475$ $\mathrm{m}^{2}$ ) from which the ventilation system (natural or mechanical) extracts $1600 \mathrm{~m}^{3} / \mathrm{h}$ of air. The temperature of the exhaust air is $18-20^{\circ} \mathrm{C}$. There are 30 residents who use $60 \mathrm{~m}^{3}$ of cold water and $22 \mathrm{~m}^{3}$ of domestic hot water a month. The heat flow of the non-insulated stairwell's domestic hot water pipes and towel dryers and insulated stairwell's main pipe network is equal to $2.7 \mathrm{~kW}$. The heat flow of the non-insulated stairwell's towel dryers and insulated domestic hot water pipes, as well as the insulated main stairwell's pipe network, is equal to $1.5 \mathrm{~kW}$. If domestic hot water system in a stairwell is renovated and water consumption level remains the same, it needs $25 \mathrm{MWh}$ of heat per year, 13 of which are used to heat the water. 


\section{A. Alternative: $H P$ recovering heat from exhaust air, $H P \_R I$}

Recovering heat from mechanical exhaust air when there is no mechanical air supply system and HP is installed in bivalent (operating together with DHS) in semi-accumulative domestic hot water preparation system in a stairwell. For the preparation of domestic hot water and maintaining the temperature in the insulated recirculation pipe network in a stairwell, a semi-accumulative domestic hot water preparation system is chosen with a water heater of the capacity 875 litres, where a $12 \mathrm{~kW}$ water heating coil is installed. Non-accumulative hot water system using HP is not analysed.

The technological scheme of HP_R1 and technical indicators are shown in Figure 1.

The technical parameters of HP_R1a and HP_R1b alternatives using refrigerant $\mathrm{R} 152 \mathrm{a}$ are presented in Table II.

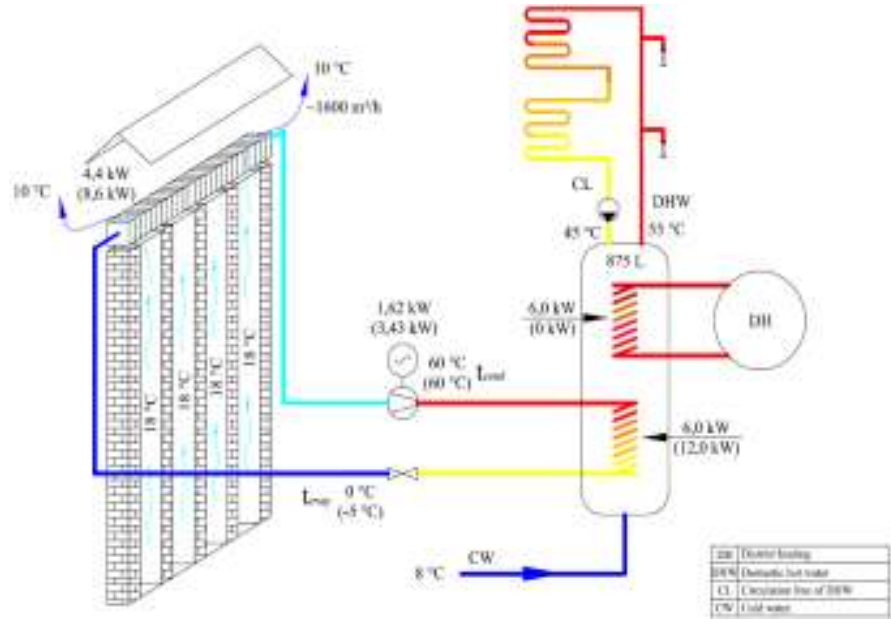

Fig. 1. Technological circuit of domestic hot water system by using HP recovering heat from exhaust air.

TABLE II

PARAMETERS OF HP SYSTEM FOR HP_R1A (50\%) AND HP_R1B (100\%) ALTERNATIVES

\begin{tabular}{|c|c|c|c|c|c|c|c|c|}
\hline & Compressor & $\mathrm{COP}$ & \multicolumn{3}{|c|}{ Evaporator } & \multicolumn{2}{c|}{ Condenser } \\
\hline & $\mathrm{kW}$ & - & $\mathrm{kW}$ & $\mathrm{t}_{\text {evap }},{ }^{\circ} \mathrm{C}$ & $\Delta \mathrm{t}_{\text {min, }}{ }^{\circ} \mathrm{C}$ & $\mathrm{kW}$ & $\mathrm{t}_{\text {cond, }}{ }^{\circ} \mathrm{C}$ & $\Delta \mathrm{t}_{\text {min, }},{ }^{\circ} \mathrm{C}$ \\
\hline HP_R1a & 1,62 & 3,7 & 4,4 & 0 & 10 & 6,0 & 60 \\
\hline HP_R1b & 3,43 & 3,5 & 8,6 & -5 & 7,5 & 12,0 & 60 \\
\hline
\end{tabular}

In the first (HP_R1a) case, a half of the capacity required by DHW system is produced by HP. The operation span of HP and DHS may vary on a daily and on a yearly basis.

In the second (HP_R1b) case, DHS heat is not used for DHW. Besides, in this case, DHS still supplies heat to the building's heating system. $\Delta \mathrm{t}_{\text {min }}$ indicate the minimal temperature difference between exhaust air and refrigerant in an evaporator and the minimum temperature difference among heated water and refrigerant in a condenser. The technically minimal values are chosen because, otherwise, HP indicators would decline or the mentioned heat exchangers would be unacceptably large.

\section{B. Alternative: $H P$ in the air handling unit, $H P \_R 2$}

Heat from mechanical exhaust air utilisation by installing HP in an air handling unit instead of a preheating section after or instead of plate recuperator in a stairwell.

In the HP_R2 alternative, $\mathrm{HP}$ is installed in an air handling unit instead of a preheating section after the plate heat exchanger (exhaust air heat recovery exchanger EAHRE).

In this case, this solution was analysed for one stairwell of a multi-apartment building. The technological calculations have been made at two external air temperatures, i.e. when the external air temperatures are $23{ }^{\circ} \mathrm{C}$ (low temperature) and $0{ }^{\circ} \mathrm{C}$ (mild temperature). The results show that the operation mode of HP should be related to the external air temperature. The mild temperature is close to the temperature of the heating season which lasts for slightly more than 200 days. The calculations cover 210 days, 110 of which have the temperature of $0{ }^{\circ} \mathrm{C}$ and more. The average value of the low temperature period is $-5^{\circ} \mathrm{C}$, and of the mild temperature period is $5.4{ }^{\circ} \mathrm{C}$. Technological issues of such regulation are not analysed in this article. This might be solved by using variable speed or two-stage compressors. Without such regulation, additional capacity of the produced heat is generated, but its usage possibilities require a more detailed analysis of the building's heat flows. Before making a decision to install HP, it is advisable to make an analysis of its produced heat capacity during the entire heating season, by considering the local external air temperature. There is a lack of valid information on ventilation units' heat exchanger seasonal temperature transfer efficiency, which is certainly lower than the nominal or declared efficiency by several tens of a per cent. The research performed by the Department of Building Energetics of the Vilnius Gediminas Technical University confirms these assumptions [20]. Table III presents the temperatures of the heat exchanger and the temperature transfer efficiency for the alternative HP_R2. 
TABLE III

TEMPERATURE OF RECOVERED HEAT AND TEMPERATURE TRANSFER EFFICIENCY OF ALTERNATIVE HP_R2

\begin{tabular}{|l|c|c|c|c|c|}
\hline & & \multicolumn{2}{|c|}{ HP_R2a $\left(\eta_{\mathrm{t}}=0,60 / 0,50\right)$} & \multicolumn{2}{|c|}{ HP_R2b $\left(\eta_{\mathrm{t}}=0,75 / 0,65\right)$} \\
\hline & & -23 to $0^{\circ} \mathrm{C}$ & $\geq 0^{\circ} \mathrm{C}$ & -23 to $0^{\circ} \mathrm{C}$ & $\geq 0^{\circ} \mathrm{C}$ \\
\hline Cold supplied air & $\mathrm{t}_{1}$ & -23.0 & 0.0 & -23.0 & 0.0 \\
\hline Hot supplied air & $\mathrm{t}_{2}$ & 0.6 & 9.2 & 7.2 & 12.1 \\
\hline Hot exhaust air & $\mathrm{t}_{3}$ & 19.0 & 19.0 & 19.0 & 19.0 \\
\hline Cold exhaust air & $\mathrm{t}_{4}$ & -6.2 & 9.5 & -12.5 & 6.6 \\
\hline Temperature transfer efficiency & $\eta_{\mathrm{t}}$ & 0.60 & 0.50 & 0.75 & 0.65 \\
\hline
\end{tabular}

When a heater of the air handling unit is changed by HP, the air of $t_{2}$ temperature from the heat recovery unit goes to the HP condenser. Afterwards, the cooled exhaust air $t_{4}$ goes to the HP evaporator.

In the alternative HP_R2c, there is no heat recovery unit, instead the exhaust air with temperature $t_{3}$ goes directly to the HP evaporator. The air exhaust from the evaporator shall have the temperature $t_{4 \text { evap. Then }} t_{1}$ temperature external air is supplied directly to the condenser. The air exhaust from the condenser and supplied to the premises shall always have temperature $t_{2 \text { cond }}$.

The technological scheme of alternative HP_R2 is shown in Figure 2.

The technological calculation results for one stairwell $\left(1600 \mathrm{~m}^{3} / \mathrm{h}\right.$ of air) of the combinations of exhaust air heat

TABLE IV

EXHAUST AIR HEAT RECOVERY HP IN AIR HANDLING UNIT - AN ALTERNATIVE HP_R2.

\begin{tabular}{|c|c|c|c|c|c|c|c|c|}
\hline & Compressor & COP & \multicolumn{3}{|c|}{ Evaporator } & \multicolumn{3}{|c|}{ Condenser } \\
\hline & $\mathrm{kW}$ & - & $\mathrm{kW}$ & $\mathrm{t}_{\text {evap }},{ }^{\circ} \mathrm{C}$ & $\Delta \mathrm{t}_{\text {min }},{ }^{\circ} \mathrm{C}$ & $\mathrm{kW}$ & $\mathrm{t}_{\text {cond, }}{ }^{\circ} \mathrm{C}$ & $\Delta \mathrm{t}_{\text {min, }}{ }^{\circ} \mathrm{C}$ \\
\hline HP_R2a $\left(\mathrm{t}_{1}=-23\right.$ to $\left.0{ }^{\circ} \mathrm{C}\right)$ & 3.06 & 3.53 & 7.76 & -30.0 & 11.0 & 10.8 & 30.0 & 10.0 \\
\hline HP_R2am $\left(\mathrm{t}_{1} \geq 0{ }^{\circ} \mathrm{C}\right)$ & 1.08 & 5.47 & 4.83 & -10.0 & 11.0 & 5.91 & 30.0 & 10.0 \\
\hline HP_R2b $\left(\mathrm{t}_{1}=-23\right.$ to $\left.0{ }^{\circ} \mathrm{C}\right)$ & 2.07 & 3.54 & 5.25 & -30.0 & 9.3 & 7.32 & 30.0 & 10.0 \\
\hline HP_R2 $\mathrm{bm}\left(\mathrm{t}_{1} \geq 0{ }^{\circ} \mathrm{C}\right)$ & 0.79 & 5.47 & 3.53 & -10.0 & 10.5 & 4.32 & 30.0 & 10.0 \\
\hline HP_R2c $\left(\mathrm{t}_{1}=-23\right.$ to $\left.0{ }^{\circ} \mathrm{C}\right)$ & 7.14 & 3.53 & 18.1 & -30.0 & 16.0 & 25.2 & 30.0 & 10.0 \\
\hline HP_R2 $\mathrm{cm}\left(\mathrm{t}_{1} \geq 0{ }^{\circ} \mathrm{C}\right)$ & 2.10 & 5.48 & 9.4 & -10.0 & 12.0 & 11.5 & 30.0 & 10.0 \\
\hline
\end{tabular}

Technologically, in the air handling unit HP which partially or fully changes the heat recovery unit and heater may operate with COP approx. 3.5 under low temperatures $\left(\mathrm{t}_{1}=-23^{\circ}\right.$ up to $\left.0{ }^{\circ} \mathrm{C}\right)$ and with COP approx. 5.5 under mild temperatures $\left(\mathrm{t}_{1} \geq 0{ }^{\circ} \mathrm{C}\right)$, irrespective of the temperature transfer efficiency of heat recovery unit. Thus, under higher temperature, COP increases about 1.5 times and the capacity of the compensator decreases by 2.8 times. Naturally, the increasing temperature transfer efficiency of the heat recovery unit requires HP with a lower capacity. When the temperature transfer efficiency increases from 0.6 up to 0.7 (i.e. by 1.25 times), HP is required, i.e. the capacity of its compressor declines by approx. 1.45 times. recovery HP (EAHRHP) with heat recovery unit of the air handling unit (alternative HP_R2) are presented in Table IV.

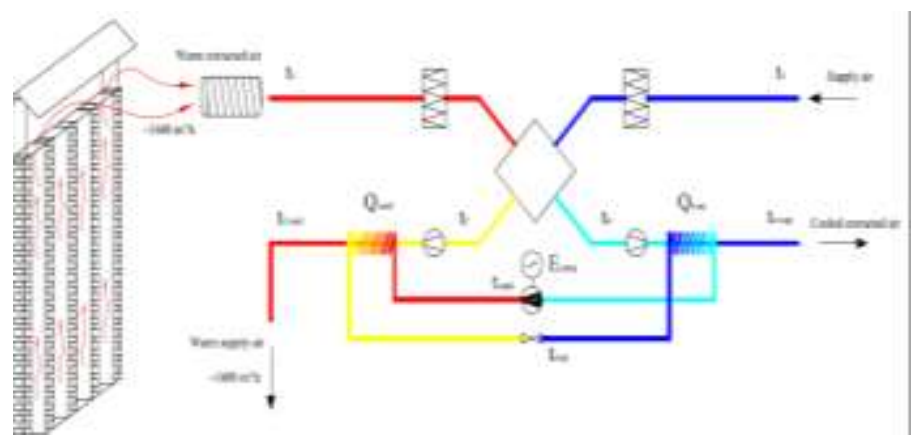

Fig. 2. Exhaust Air Heat Recovery Heat Pump-EAHRHP in air handling unit.

\section{Alternative: Waste water resource heat pump, $H P \_R 3$}

In alternative HP_R3. heat from waste water of the building with 4 stairwells and 40 apartments is used for HP which heats the domestic hot water by recirculation. In this case, all the waste water from the building is collected in one receptacle where the HP evaporator is installed. A separate receptacle for each stairwell would require additional investments and work. An example of such a receptacle with evaporator is [21].

The technological scheme and technical parameters of HP_R3 or the so-called waste water resource HP (WWRHP) alternative are shown in Figure 3.

It is assumed that the existing DHW recirculation pipes are partially insulated (except of towel dryers) and because of that, the heat flow is reduced by two times. 


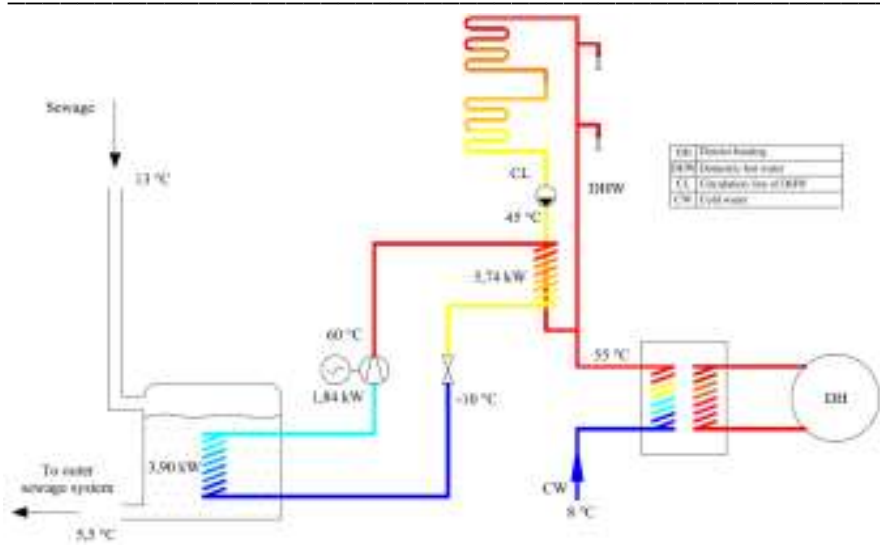

Fig. 3. Waste water resource heat pump (WWRHP) - principle technological scheme and technical indicators of the alternative HP_R3.

\section{ENERGY, ECONOMIC, AND ENVIRONMENTAL EVALUATION OF ALTERNATIVES}

The so-called $3 \mathrm{E}$ evaluation has been performed. The aggregate energy, economic and environmental indicators of the alternatives are presented in Table V. The comments and not yet discussed basic assumptions are presented below.

Heat price from DHS is $22.4 \mathrm{ct} / \mathrm{kWh}$, incl. VAT, and electricity price - $45 \mathrm{ct} / \mathrm{kWh}$, incl. VAT.

HP_R1a system for a stairwell (bivalent water heating when $\mathrm{HP}$ is $6 \mathrm{~kW}$ and DHS $-6 \mathrm{~kW}$, twin coil accumulation tank of 875 litres) costs LTL 31.5 thousand. $\left(66 \mathrm{LTL} / \mathrm{m}^{2}\right)$. HP_R1b system for a stairwell (water heated only by HP when HP is $12 \mathrm{~kW}$, twin coil accumulation tank of 875 litres) costs LTL 34.3 thousand $\left(72.2 \mathrm{LTL} / \mathrm{m}^{2}\right)$.

TABLE V

AGGREGATE INDICATORS OF ALTERNATIVES

\begin{tabular}{|c|c|c|c|c|c|c|c|c|}
\hline \multirow{3}{*}{ Alternative } & \multirow{3}{*}{$\mathrm{COP}$} & \multicolumn{2}{|c|}{ Produced heat } & \multirow{3}{*}{$\begin{array}{c}\begin{array}{c}\text { Investments } \\
\text { to heated } \\
\text { area }\end{array} \\
\text { LTL***/m² }\end{array}$} & \multirow{2}{*}{\multicolumn{2}{|c|}{$\begin{array}{c}\text { Cost of heat produced by } \\
\text { HP }\end{array}$}} & \multirow{3}{*}{$\begin{array}{c}\text { Simple } \\
\text { payback time } \\
\text { year }\end{array}$} & \multirow{3}{*}{$\begin{array}{c}\mathrm{CO}_{2} \\
\text { decrease } \\
\%\end{array}$} \\
\hline & & HP & $\mathrm{DH}^{*}$ or & & & & & \\
\hline & & \multicolumn{2}{|c|}{ MWh } & & $\mathrm{ct} / \mathrm{kWh}$ & $\begin{array}{l}\% \text { of DHS } \\
\text { price }\end{array}$ & & \\
\hline HP_R1a1 & 3.7 & 16.7 & $8.3^{*}$ & 66.2 & 12.15 & 54.2 & 19 & 14.8 \\
\hline HP_R1a2 & 3.7 & 12.5 & $12.5^{*}$ & 66.2 & 12.15 & 54.2 & 25 & 11.1 \\
\hline HP_R1b & 3.5 & 25.0 & $0.0^{*}$ & 72.2 & 12.86 & 57.3 & 15 & 17.7 \\
\hline HP_R2a & 3.53 & 14.5 & $19.2 * *$ & \multirow{2}{*}{57.0} & 12.75 & 56.8 & \multirow{2}{*}{9} & \multirow{2}{*}{16.9} \\
\hline HP_R2am & 5.47 & 11.3 & $10.0^{* * *}$ & & 8.23 & 36.7 & & \\
\hline HP_R2b & 3.53 & 9.8 & $23.9 * *$ & \multirow{2}{*}{50.0} & 12.75 & 56.8 & \multirow{2}{*}{11} & \multirow{2}{*}{12.3} \\
\hline HP_R2bm & 5.47 & 8.4 & $12.9 * *$ & & 8.23 & 36.7 & & \\
\hline HP_R2c & 3.53 & 33.7 & $0.0^{* *}$ & \multirow{2}{*}{63.0} & 12.75 & 56.8 & \multirow{2}{*}{5} & \multirow{2}{*}{33.5} \\
\hline HP_R2cm & 5.47 & 21.3 & $0.0^{* *}$ & & 8.23 & 36.7 & & \\
\hline HP_R3 & 3.10 & 49.4 & $0.0^{*}$ & 14.2 & 14.52 & 64.7 & 7 & 7.0 \\
\hline
\end{tabular}

$* * * 1 €=3.4528 \mathrm{LTL}$

Alternative HP_R2 - the use of mechanically exhaust air heat from each stairwell when there is mechanical air supply, installing HP in an air handling unit instead of preheating section after ( $a$ and $b$ ) and instead of (c) plate recuperator. Its technological scheme is shown in Figure 2. As Table V shows, the payback time of alternative HP_R2a is 9 years. It should be noted that in alternative $H_{-} R_{2} \mathrm{c} / 2 \mathrm{~cm}$ the compared ventilation system is without heat recovery. Thus, when the reference variant is highly inefficient, the results of the alternative variant at first approach look quite satisfactory.

In alternative HP_R3, HP is installed for the whole building and it uses a R152a cooler. The characteristics of this HP: the evaporator of $3.90 \mathrm{~kW}$, the compressor of 1.84 $\mathrm{kW}$, the condenser of $5.74 \mathrm{~kW}$, and its $\mathrm{COP}=3.10$. The temperature of sewage flowing into the collector with evaporator is $13^{\circ} \mathrm{C}$ and the one flowing out of the collector $5.5^{\circ} \mathrm{C}$. This system for the building would cost approx. LTL 27 thousand, incl. VAT $\left(14.2 \mathrm{LTL} / \mathrm{m}^{2}\right)$. The operation of a well insulated recirculation domestic hot water loop of DHW requires $50 \mathrm{MWh}$ of heat per year. The installation of this system would save LTL 3.9 thousand per year. The payback period reaches almost 7 years.

This system could operate together with systems HP_1 or HP_2, besides, it operates all year round.

The environmental evaluation could be based on the absolute and percentage (counted for the production of heat capacity) decrease of $\mathrm{CO}_{2}$. There is an assumption that when heat is produced using natural gas $(80 \%)$, fuel oil $(10 \%)$, and biomass $(10 \%)$, the heat emission factor, depending on the fuel, is $0.22 \mathrm{~kg}_{\mathrm{CO} 2} / \mathrm{kWh}$. For the evaluation of the pollution of the used electricity, the Lithuanian power-station emission factor $0.634 \mathrm{~kg}_{\mathrm{CO} 2} / \mathrm{kWh}$ is used. The analysed alternatives of HP installation in five building services systems allow reducing $\mathrm{CO}_{2}$ by approx. 10-20\%

It should be mentioned that, from the environmental point of view, none of the analysed alternatives of HP installation in building services systems are better than DHS where biomass covers approx. $50 \%$ and more of fuel balance. 


\section{CONCLUSIONS}

1. As the performed analysis shows, if the thermal characteristics of new or renovated buildings increase, air as well as water warm flows from the building, change very slightly, thus they should receive more attention for energy efficiency of their usage and particularly for HP applications.

2. Installation of HP in the air handling unit, where it uses heat from exhaust air, and in the waste water receptacle, where it uses heat of this water, from the payback period point of view is economically attractive and is worthwhile to be supported in the pilot projects. In each case, the size and the operation strategy of HP must be calculated under specific climatic and operating conditions.

3. According to the simplified environmental assessment based on a $\mathrm{CO}_{2}$, HP does not have an advantage over DHS which burns great quantities of biomass. In order to evaluate all the environmental effects, it is necessary to use more sophisticated methods of assessment.

\section{REFERENCES}

1. Chua K. J., Chou S. K, Yang W. M. Advances in heat pump systems: A review. Applied Energy, 2010, vol. 87, N 12, p. 3611-3624.

2. Riffat S. B., Gillott M. C. Performance of a novel mechanical ventilation heat recovery heat pump system. Applied Thermal Engineering, 2002, vol 22, N 7, p. 839-845.

3. Fracastoro G. V., Serraino M. Energy analyses of buildings equipped with exhaust air heat pumps (EAHP). Energy and Buildings, 2010, vol. 42, N 8, p. 1283-1289.

4. Kjellsson E., Hellstrom G., Perers B. Optimization of systems with the combination of ground-source heat pump and solar collectors in dwellings. Energy, 2010, vol. 35, N 6, p. 2667-2673.

5. Zogou O., Stamatelos A. Optimization of thermal performance of a building with ground source heat pump system. Energy Conversion and Management, 2007, vol. 48, N 11, p. 2853-2863.

6. Kalz D. E., Wienold J., Fischer M., Cali D. Novel heating and cooling concept employing rainwater cisterns and thermo-active building systems for a residential building. Applied Energy, 2010, vol. 87, N 2, p. 650-660.

7. Gan G., Riffat S. B., Chong C.S.A. A novel rainwater-ground source heat pump - Measurement and simulation. Applied Thermal Engineering, 2007, vol. 27, N 2-3, p. 430-441

8. The CLASS 1 CONCERTO project [online]. Available: http://www.class1.dk.

9. The Green Solar Cities CONCERTO projects [online]. Available: http://www.greensolarcities.com.

10. The ProHeatPump an Intelligent Energy Europe project [online]. Available: www.proheatpump.eu/default.htm.

11. The Sustainable Energy in New building-market inTROduction (SENTRO) an Intelligent Energy Europe project [online]. Available: http://www.sentro.eu.

12. Joelsson A., Gustavsson L. The need for a life cycle perspective on the passive house concept. In. 1st Nordic passive house conference Passivhus Norden 2008, April 4-5, 2008. Proceedings. Norway, 2008, p. 162-168.

13. EPC Directive 2009/125/EC.

14. Andresen I., Ellehauge K., Karlsson B., Nieminen J. Solar heating systems for passive houses in the Nordic countries - An Overview. In.
1 st Nordic passive house conference Passivhus Norden 2008, April 4-5, 2008. Proceedings. Norway, 2008, p. 336-344.

15. Kalema T., Pylsy P. Low-energy house concepts for Nordic countries. In. 1st Nordic passive house conference Passivhus Norden 2008, April 4-5, 2008. Proceedings. Norway, 2008, p. 66-73

16. Bühring A. Development and Measurement of Compact Heating and Ventilation Devices with Integrated Exhaust Air Heat Pump for HighPerformance Houses. In. 8th IEA Heat Pump Conference, Las Vegas, USA, May 30 - June 2, 2005.

17. Zukowski M., Sadowska B., Sarosiek W. Assesment of the cooling potential of an earth-tube heat exchanger in residential buildings. In. The 8th International conference Environmental engineering, Vilnius, Lithuania, May 19-20, 2011. Selected papers. Vol. 2. Vilnius, 2011, p. 830-834.

18. Schmid F. Sewage water: interesting heat source for heat pumps and chillers. Swiss Federal Office of Energy, 2009. 12 p.

19. Gutzwiller S., Rigassi R., Eicher H. Abwasserwärmenutzung Potenzial, Wirtschaftlichkeit und Förderung. Swiss Federal Office of Energy, Berne, 2008. 78 p.

20. Jonkaitis T., Juodis E. Realus ir programiškai sumodeliuotas šiluminis bei ekonominis védinimo sistemy šilumos atgavimo įreginių efektyvumas. In. National scientific conference Building service systems, Vilnius Lithuania, April 26-27, 2007. Selected papers. 2007, p. $11-19$.

21. Kalberer D. Energie aus Abwasser - aktueller denn je, Spektrum Gebäude Technik, 2007, vol. 4, p. 40-41.

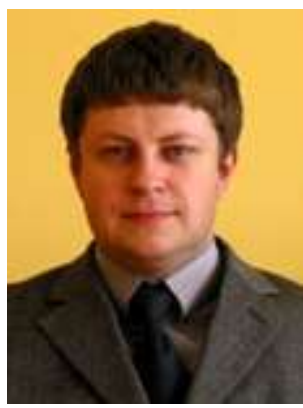

Giedrius Siupsinskas, Dr. assoc. professor, VGTU, Faculty of Environmental Engineering, Department of Building Energetics. In 20072001 worked as assistant in Heating and Ventilation Department. Since 2007 he is assoc. professor of the same department. The main research areas are renewable energy sources, energy performance of buildings and district heating. $\mathrm{He}$ participated in local and international projects related to energy efficiency. He is the author of more than 20 publications. In 2007 he defended $\mathrm{PhD}$ thesis "The coherent modernization of district heating system" in VGTU. He made internship in Lithuanian Energy Institute, University of Iceland, and Aalborg Technical University (Denmark).

Address: Sauletekio Ave. 11, LT-10223, Vilnius, Lithuania

E-mail: giedrius.siupsinskas@vgtu.lt

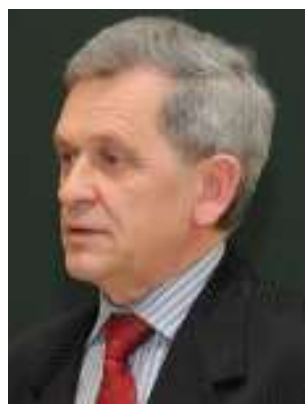

Vytautas Martinaitis, Professor, dr. habil. of VGTU, Building Energetics (until 2009.09 Heating and Ventilation) dep. Prof. Vytautas Martinaitis has been part of academic staff of this department since 1974 in Kaunas Technology University and since 1989 - in VGTU, in 1992-1996 dean of Environmental Engineering Faculty, since 2002 head of Building Energetics dep. of VGTU. The main research area is energy efficiency of sustainable housing: thermodynamic, exergy and life cycle analysis. He has participated in local and international projects related to energy efficiency. He is the author of more than 110 publications. He has Civil Engineer Diploma (1972) and two steps doctoral degree diploma. $\mathrm{PhD}$ thesis "Research and development of turboprop gas burner for greenhouse microclimate system" was defended in Polytechnic Institute of Byelorussia (1982). Doctor Habilitus Thesis "Thermodynamical analysis model of building life cycle" was defended in Kaunas Energy Institute (2000).

E-mail: vytautas.martinaitis@vgtu.lt

Vytautas Martinaitis, Giedrius Šiupšinskas. Siltuma sūkṇu integrēšanas iespējas daudzdzīvokḷu ēkās.

Tehniskie risinājumi siltuma sūkṇu uzstādīšanai privātmājās ir labi pazīstami, bet to integrāaija jau esošās sistēmās daudzdzīvokḷu ēkās notiek diezgan reti. Siltuma sūkṇa tehnoloğiju bieži sauc par atjaunojamo, bet to integrācija daudzdzīvokḷu ēkas esošajā siltumapgādes sistēmā sekmē tehnisko, ekonomisko un ekolog̣isko izaugsmi kopumā. Darba mērkis ir siltuma sūkṇu integrācijas iespēju izpēte esošajās siltuma/sanitārajās sistēmās daudzstāvu dzīvojamās ēkās. Vismazākā telpa, kurā iespējams integrēt siltuma sūkni, ir daudzstāvu ēkas kāpṇu telpa. Siltuma sūkṇu izmantošanas iespējas atsevišķā dzīvoklī netika aplūkotas. Detalizēti tika analizētas trīs alternatīvas: HP_R1 - siltuma sūknī saražotā gaisa siltuma izmantošana karstā ūdens sagatavošanai; HP R2 - siltuma sūknī saražotā gaisa siltuma izmantošana telpu apsildei, pieslēdzoties rekuperatora vai mehāniskās ventilācijas sistēmai; HP_R3 - èkas notekūdeņu siltuma izmantošana siltuma sūknī karstā ūdens sagatavošanai. Alternatīvu analīze un aprēḳini tika veikti reālām daudzdzīvokḷu ēkām Brištonas pilsētā (Lietuva) projekta CONCERTO EcoLife ietvaros. Analīzē ieklauti arī alternatīvu ekonomiskie un ekoloǵiskie novērtējumi. 